\title{
The Role of Urban Slums in the Evolution of Megacities: A case of Nima and Old Fadama, Accra, Ghana
}

\author{
Eunice YORGRI ${ }^{1}$, Department of Urban and Rural Planning, School of Architecture, Harbin \\ Institute of Technology, 92 West Dazhi Street, Harbin, China, 150001 \\ Prof. Leng HONG ${ }^{2}$, Department of Urban and Rural Planning, School of Architecture, Harbin \\ Institute of Technology, 92 West Dazhi Street, Harbin, China, 150001
}

\begin{abstract}
Urban areas are contributing unprecedentedly in modelling the social, cultural, economic, environmental and physical development of the globe as they are perceived as basket of opportunities to the poor. This phenomenon has undoubtedly resulted in the influx of poor migrants particularly in the global south and consequently causing the proliferation of slums. This is indirectly influencing the growth of megacities due to increasing population amidst limited infrastructure. So far, limited research has been conducted into the role of poor rural migrants in contributing to the growth of megacities. The study also attempted to propose sustainable planning strategies in guiding future urban planning. The case study used both primary and secondary data collection methods. In all, 304 questionnaires were administered in April 2017 (Nima=146 and Old Fadama=158). From the study, $46 \%$ of the respondents in Nima hail from the Northern part of Ghana and 14\% from the Volta Region. On the other hand, $49 \%$ of the respondents in Old Fadama come from the Northern part of Ghana and 22\% from the Volta Region. Both Nima and Old Fadama have high figures on migrant population which means a fair contribution to the growth of Accra as a megacity. Therefore, spatial equality through a comprehensive, integrated and universal national development(UND) covering all sectors should be employed. Also, economic opportunities upgrading which is essential for slum and rural communities in Ghana should be considered. Further research on how cities in Ghana are planning towards becoming megacities is prudent.
\end{abstract}

\section{Keywords}

Megacities, Rural-Urban Migration, Urban Slums, Nima, Old Fadama

\section{Introduction}

"Across the globe and in a short amount of time, we've given up the tractor for the city bus, the open landscape for one of brick and mortar."

In recent years, world population has grown exponentially including urban population which is said to be first in the history of mankind. Urbanization trends closely mirror the universal patterns of economic development and progress in industrialization. At the beginning of the 
20th century, only $13 \%$ of the global population lived in cities and only sixteen cities had a population of least one million. Currently, approximately, four hundred cities have populations of more than one million, majority of which are located in the global south(Cohen, 2006). Cities can be places of opportunity, creativity, innovation and of peaceful co-existence across cultural and ethnic divides, thereby generating a high quality of life for residents(Lucci et al., 2015). This basically serves as incentives for rural migrants who try to escape poverty, low levels of development and the impact of climate change. As these poor migrants unprecedentedly influx cities, they also contribute to the rapid growth of cities, albeit sometimes they reside in poor neighbourhoods such as slums. Little attention is given to the impact of poor migrants in the growth of megacities. Therefore, this study considers the role slum plays in the rapid growth of cities by focusing on rural urban migration using two popular slum communities in Accra as case study. The case study is home to majority of migrants in Ghana's capital city. Per the definition by the Ghana Statistical service, a place with a population of more than 5000 residents is termed urban(GSS, 2012). Considering this definition, it means that both Nima and Old Fadama (OF) are urban within the broader urban fabric (city within a city). Assuming, slum populations (majority being migrants) did not exist in cities, then although there maybe megacities, the rate of growth may be significantly low.

\subsection{Urbanization and Megacities}

Urbanization is commonly associated with economics such as improved job opportunities, a centralized market, better pay and higher individual affluence, attracting people into cities(Cohen, 2006). For the first time in history, more people globally live in cities than in rural areas and this has been attributed to people migrating from rural regions into cities and the reclassification of areas(Habitat, 2016).

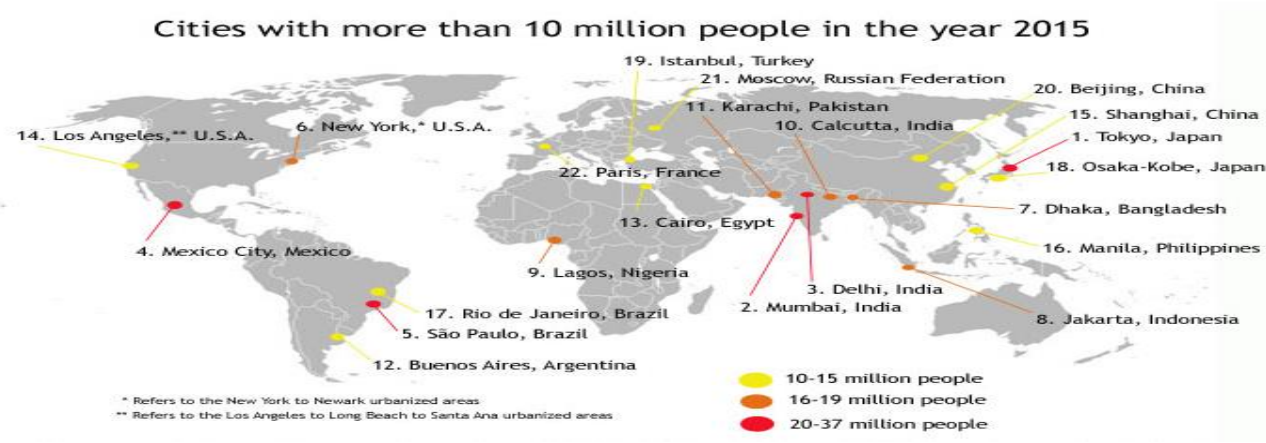

Fig.1 Global Mega Cities in 2015, Source:(Institute, 2013, Learner, 2017)

Globally, 55\% of the world's population reside in cities and this figure is expected to increase to $68 \%$ by 2050 (DESA, 2018). In some few years to come, the rural population will almost be approaching its zenith (see figure 2). The black and red arrows as shown in figure 2, visually presents an estimated gap developing between rural and urban population. As the years go by, the rural population is declining whilst the urban population is increasing, gradually resulting in the growth of megacities.

Megacities are considered as cites with a population of ten million and above. In the 1950s, only Tokyo in Japan and New York in the United States of America, were the first known megacities of the world(Munich, 2005, Taubenböck et al., 2012). In 2015, approximately 21 megacities existed globally (see figure 1). 


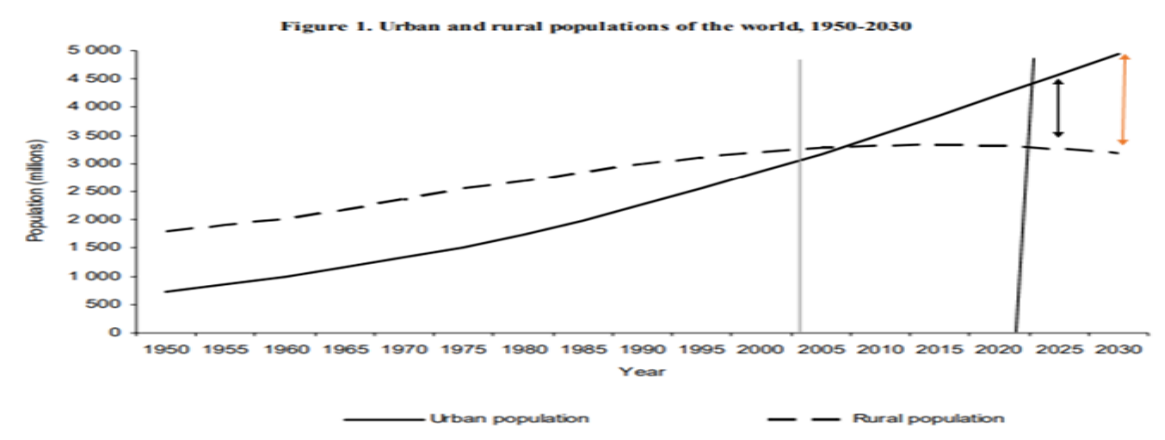

Fig.2 Rural and Urban Growth from 1950-2030, Source; (Nations, 2002)

Currently Africa and Asia host approximately $90 \%$ of the world's rural population. Almost half of the global urban population live in areas of less than 500, 000 dwellers. However, one in eight people live in megacities with more than 10million inhabitants. By 2030, it is forecast that there will be approximately 43 megacities in the world, majority of which will be located in the global south(DESA, 2018). Megacities albeit maybe be motivated by urbanization, slum settlements are also the bi-products of unplanned urbanization, which indirectly contribute to the creation of megacities.

\subsection{Megacities and Slums}

Slum creation has been a dominant characteristic of rapid urbanization in the global South and is expected to continue well into the future(Lucci et al., 2015). UN-Habitat estimated that over $60 \%$ of urbanites in Sub-Saharan Africa live in slums as compared with an average of $37 \%$ across the global south(UN-Habitat, 2015). Although, no country has achieved middle-income status without urbanizing, the creation of megacities and slums is one of the greatest transformation of the 21st century(Lucci et al., 2015). Slums are massive as megacities and as cities keep experiencing exponential growth, so are urban slums. Slums despite the lack of urban infrastructure, are morphing into mega slums. About 1 billion people currently live in slum settlements, that is, almost a third of the world's urban population (UN DESA, 2013). In the 1970s the United Nations (UN) coined the term "megacity" to designate urban areas with eight million inhabitants and over. In the 1990s, they raised this threshold to ten million. Today, 22 cities and urban regions have reached this population figure, four of them in industrialised countries(Munich, 2005). Around $9 \%$ of the world's urban population - about 280 million people - currently live in megacities, and this figure is likely to rise to 350 million over the next ten years(Munich, 2005)

Slums, mostly develop as a result of a combination of factors such as rapid urban population growth, lack of affordable housing and poor governance. In some cases, the pace of urbanization outstrips government's capacity to provide the framework for affordable housing (e.g. land, infrastructure, access to utilities) for an increasing population. Also, governments are unwilling to act as they believe that providing services and better conditions to the poor will attract more people and cause slums to grow further. This means slums actually grow as they remain limitedly serviced for long periods of time (Lucci et al., 2015). 
Sub-Saharan Africa is the region with the largest percentage of the urban population residing in slums, that is, over $50 \%$. Implying that, Sub-Saharan Africa is the region where the rate of slum growth has been closer to that of general urban population growth (Lucci et al., 2015).

Ghana amongst the most urbanized and rapidly urbanizing economics in Africa. In the past three decades, the number of city dwellers has risen from 4 to 14 million and about six million people live in slums. Urban growth exerts intense pressure on government and municipal authorities to provide affordable housing, public services and jobs. Statistics from the World Bank shows that, 53\% of the population lived in towns and cities in 2014. The urban population increased from 4million to 14million since 1984, with an estimated 6 million (39\%) living in slums(Habitat, 2014). Recently, there are approximately 256 slum pockets spread across the country majority of which are located in Accra. This phenomenon has contributed significantly to the growth in population of the Greater Accra Region, although the contribution of natural increase cannot be overlooked.

\section{Study Sites and Methodology}

\section{1 Study Sites}

Ghana had a population of 24.2 million during the last census of which over half of the population lived in urban areas(UN-Habitat, 2011, GSS, 2012). Both Nima and Old Fadama (OF) are slum settlements located in the Greater Accra Region of Ghana. They are amongst the numerous slum pockets (256 slum pockets) spread throughout the country. Nima and OF are peculiar as a result of their long standing history, population of migrants and the continuous influx of migrants into these areas. In details, Nima is located directly north of the ring road and within the Ayawaso East Metropolitan Area of the Accra Metropolitan Assembly (AMA)-figure 3. The low-income residential neighbourhood has a total population of approximately 70,000 and it is settled on 1.59 square kilometers of land(GSS, 2012, Owusu et al., 2008). The population of Nima has increased exponentially considering that in 1960 , the average population density in the area was 25,846 residents per square kilometer and 43, 478 people by the year 2000 respectively(Kang et al., 2010). On the other hand, Old Fadama is located within the Ashiedu Keteke Metropolitan Area of the AMA-figure 3). The slum area occupies a 31.3 hectares of land along the Odaw River and the Korle Lagoon. From the 2009 community enumeration, the community had a population of 79,684 giving a population density of 2424.18 persons per hectare(Settlements, 2010). However, the current population of the area is estimated at 100,000 people, making it densely populated. The now "matured slum" emerged in the 1980s and has become one of the most populous in Accra. 


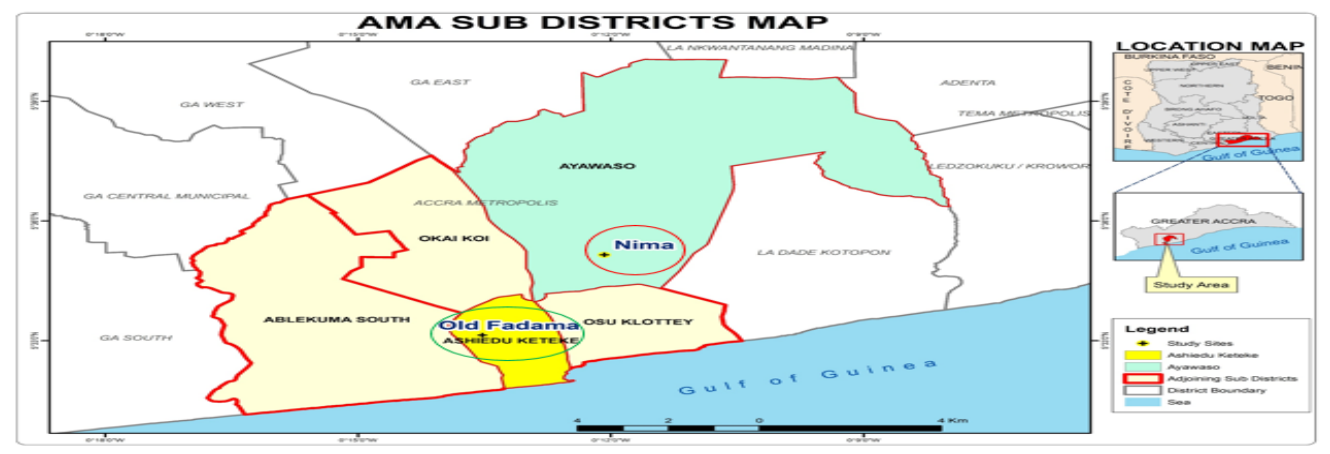

Fig. 3 Location of Nima and Old Fadama on the Map of the AMA

During the colonial period and independence era, urban planning in Accra did not take native and migrant communities into account. They were largely overlooked by the state and left unregulated(Obeng-Odoom, 2010), hence more people settle in the areas but remain unrecognized, particularly migrant communities, thereby leading to population increase and slum formations.

\subsection{Methodology}

Research is the pursuance of truth through study, observation, comparison and experiment(Kothari, 2004). In order to get an in-depth knowledge on the problem, this study used the case study method and non-probability sampling (purposive and snowball). The main reason for opting for this method of data collection is that, slum residents are difficult to get and their willingness to participate in surveys is minimal (sometimes they feel surveys are a form of mockery to them-more surveys less actions). Therefore, the researcher used non-probability sampling design instead of probability sampling design. The slum areas were selected based on the population of migrants. The researcher is impartial and the data analysis was done without prejudice, without no element of bias. In all, 304 questionnaires were administered to both Nima and OF respondents. Respondents in Nima were administered 146 out of the 150 questionnaires sent to the community, whilst respondents in OF were administered 158 questionnaires out of 160 questionnaires. The reason for the disparity is based on the respective population of the slum community and the willingness of respondents to participate in the survey. Some residents were not willing to participate and also respondents who agreed to participate did not answer the questions satisfactorily, hence were not added in the analysis.

Also, the researcher used secondary data from earlier researches relevant to this study such as journal articles, reports, reviews and unpublished documents from online portals and news, which were duly cited and referenced.

One major limitation of this study is the availability of residents and their willing to participate in the survey.

\section{Results and Discussions}

Urbanisation is associated with rural-urban migration, as workers move from less productive activities in agriculture to more productive activities in urban areas. But rural-urban migration can also happen as a result of searching for better amenities, to escape rural 
poverty (even in the absence of prospects of a formal job in urban areas) or from conflict, natural disasters and social tensions. However, rural-urban migration is actually not the dominant factor behind urban population growth in developing countries, particularly in Sub-Saharan Africa(Lucci et al., 2015). Although the agents of urbanization may be specific to countries, the significant characteristics such as rural urban migration cannot be overemphasized. Therefore, the focus of this study is to examine the role of slums in the growth of megacities through the influx of poor rural migrants.

\subsection{Causes of Slums in Accra}

The creation of megacities and slum formation can be attributed to multifaceted factors. Slum developments especially in Accra relates to rural-urban migration (lack of jobs at the places of origin) and the lack of affordable housing. Financial and lack of job availability are the internal factors contributing to slum development(Srinivas, 2005). Rapid rural-urban migration, infrastructure inadequacy and economic retrogression are also some of the factors causing slum formation according to the UN-Habitat report in 2007(Habitat, 2006).

\subsubsection{Migration}

According to the former UN-Secretary General, Ban Ki-moon, migration is an expression of the human aspiration for safety, better future and dignity, forms part of the social fabric and also the very make-up as a human family (2013 High-level Dialogue on International Migration and Development). Migrants constitute more than a billion of the global population and one-seventh of the universal population, with international migrants making up an estimated population of 244 million and internal migrants constituting 763million(Tacoli et al., 2015). Migration may occur within a country from urban to rural, urban to urban, rural to rural, or rural to urban. Also, migrants may move willingly to live in a better place and to improve their financial status and this is predominant among ruralurban migrants in Ghana(Awumbila et al., 2014). Table 1 gives an overview of the differences given by respondents of both Nima and Old Fadama between their places of origin and current destination.

Table 1 Differences between Place of Origin and Destination

\begin{tabular}{l|l}
\hline ORIGIN & DESTINATION \\
\hline Peaceful & Poor Living Condition \\
No Tertiary Institutions & High Cost of Living \\
Cheap Accommodation & Good for Business \\
Low Level of Development & Great Opportunities \\
Enough Space & Low Cost of Rent \\
Lack of Jobs & Good Schools \\
Good Sanitation & Too Crowded \\
Different Level of Civilization & \\
\hline
\end{tabular}

These factors are very important to consider for they significantly form the basis for the movement of rural dwellers to reside in cities. From the survey, $57 \%$ of respondents in Nima migrated to Accra in search of jobs whilst $7 \%$ moved because of education. Also, $5 \%$ of respondents migrated as a result of the low level of development in the area, whilst $6 \%$ moved because of marriage. One percent of respondents migrated due to proximity to work, $1 \%$ due to the lack of electricity and $1 \%$ migrated because of trade. Again, $11 \%$ of respondents migrated because of the population of the area, whilst $10 \%$ of respondents did not mention the reason for migrating. For OF on the other hand, $64 \%$ of respondents migrated to find jobs whilst $7 \%$ migrated because of education and $3 \%$ because of trade. Furthermore, $1 \%$ went for on a visit, whilst $1 \%$ migrated due to the death of mother. Added, 
eleven percent of respondents migrated due to marriage, whilst $2 \%$ as a result of cost of rent. Three percent of the respondents migrated due to the population of the area whilst $8 \%$ did not give a specific reason. From the above findings, it's crystal clear that, migrants have diverse and personal reasons for moving and settling at a place (figure 4). To some respondents, the low level of development in the area is no issue, whilst to others it caused them to leave. However, some factors such as good schools (Education), marriage and finding a job are significant reasons for majority as it constitutes a major part of their socioeconomic development. Therefore, integrated spatial development should form the pivotal part of government policies, particularly in the global south.

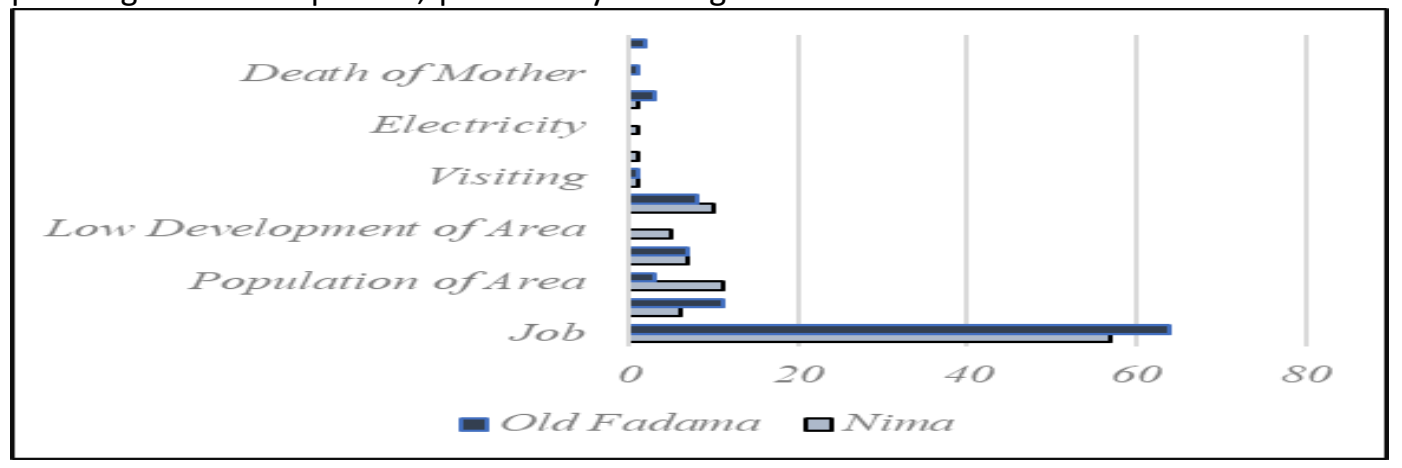

Fig. 4 Respondents' Reasons for Migration

According to the World Economic Forum Report (2017), the push factors of migration include lack of employment opportunities, unsustainable livelihood and rural poverty whist the pull factors include employment opportunities, pursuit of specialized education, better income and prospects for wealth creation, among others(Baffoe and Matsuda, 2017). All the factors are very evident in reasons posit by slum dwellers for migrating from their respective places of origin.

Respondents hailed from different parts of the country including neighbouring countries to settle in Nima or OF. The findings show that, $3 \%$ of the respondents in Nima come from the Central region of Ghana, $1 \%$ from Western Region, $6 \%$ from the Ashanti Region, $21 \%$ from the Northern Region, 12\% from the Upper East Regions, whilst 6\% are indigenes (figure 5). The results for OF also show that, $4 \%$ of the respondents, hail from the Central Region, $1 \%$ from Western Region, 3\% from the Ashanti Region and 35\% from the Northern Region (figure 5).

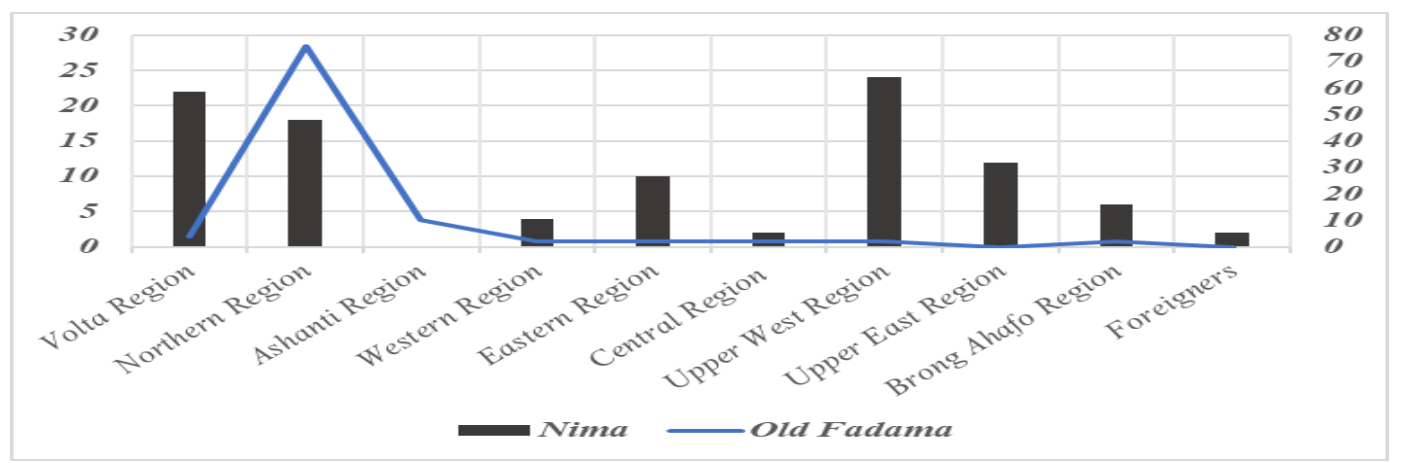

Fig. 5 Respondents' Places of Origin

Despite the fact that respondents migrated from different places, they all hope for good and better living including job acquisition, good schools, hospitals and incredible opportunities. One of the major differences between the place of origin and destination for both 
respondents of Nima (78\%) and Old Fadama (54\%) is the unavailability of jobs and opportunities (push factors). Before deciding to leave the rural area, they feel the abstract beckoning of life in the cities which keeps burgeoning the interest to live in cities which comes as a result of spatial equality. This phenomenon re-iterate that economic improvement for slum dwellers both at the place of origin and destiny can significantly reduce migration, hence decelerating the pace of the growth of megacities, self- sufficient and resilient to forces of poverty. Also, when rural areas are economically empowered, the possibility of abled bodies from the rural areas drifting to cities may be curtailed. Slum dwellers who are young and detest consistent monitory of parents see being away from home and fending for themselves as freedom. Parents must take responsibility of their children and not to push them into child labour and a law restricting child labour should be enacted and stringently and effectively enforced. This has become vital as some respondents in OF are so young to be out on their own. For the girls amongst them, they end up being impregnated, hence contributing to the natural increase in the slum. Most often, they stay in the slums for ages and to some extend start their families in the slums (figure 8). All these account for the creation of mega slums, invariably leading to the creation of megacities. Since the destination provides jobs through the proximity of markets, where they indulge in manual and menial jobs (needing no skill or certificate) such as kayayi, truck pushing, assisting food vendors among others and coupled with the affordable cost of living, they will continue to live there and new entrance will join, gradually leading to the creation of mega slums (mega slums are descendants of megacities, figure 9).

In a nutshell, the responses outlined by respondents were categorised into high impact factors and low impact factors. The high impact factors are the ones relating to government policies and the low impact factors are personal factors (Table 2).

Table 2 Classification of Factors Given by Respondents

\begin{tabular}{|c|c|c|c|}
\hline PUSH FACTORS & PULL FACTORS & $\begin{array}{ll}\text { HIGH } & \text { IMPACT } \\
\text { FACTORS } & \\
\end{array}$ & $\begin{array}{ll}\text { LOW } & \text { IMPACT } \\
\text { FACTORS } & \end{array}$ \\
\hline $\begin{array}{ll}\text { Low Level of } \\
\text { Development }\end{array}$ & Job Opportunities & Job Search & Visit \\
\hline $\begin{array}{l}\text { Population of the } \\
\text { Area }\end{array}$ & Education & Education & Marriage \\
\hline $\begin{array}{l}\text { Visits } \\
\text { Death of Mother }\end{array}$ & $\begin{array}{l}\text { Trading } \\
\text { Proximity to Work }\end{array}$ & $\begin{array}{l}\text { Trading } \\
\text { Low Cost of Rent }\end{array}$ & $\begin{array}{l}\text { Death of Mother } \\
\text { Population of the }\end{array}$ \\
\hline $\begin{array}{l}\text { Lack of Social } \\
\text { Infrastructure }\end{array}$ & Low Cost of Rent & $\begin{array}{l}\text { Low Level of } \\
\text { Development } \\
\text { Nearness to Work }\end{array}$ & Area \\
\hline
\end{tabular}

The high impact factors according to this study, are the factors that are relevant and difficult to solve by governments in a short term and are major contributory factors to causing people leave their places of origin whiles the low impact factors according to this study are the factors that also contribute to slum development in infinitesimal cases. The reason for this categorization is to aid in development plans and also present a roadmap in resolving slum challenges from their root causes (For example, $57 \%$ and $64 \%$ of respondents in both Nima and Old Fadama migrated due to lack of jobs and in search of jobs respectively).

The findings show that $75 \%$ of respondents in OF relocated to the area whilst $25 \%$ did not relocate to the area. Also, $82 \%$ in Nima relocated to the area whilst $18 \%$ did not relocate to 
the area (figure 6).

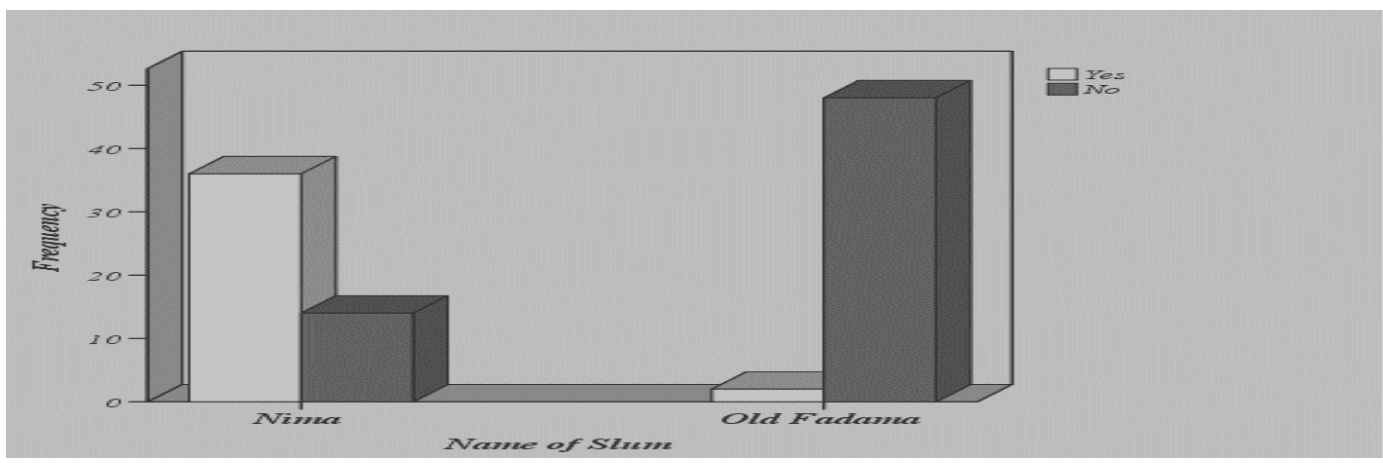

Fig. 6 Respondents Born in the Slum

The place of abode of every individual is paramount, despite the myriad of challenges or no matter how scintillating the place may look. However, even within the city, there are push and push factors that forces slum dwellers move from one slum to another. As already elucidated above, there are other reasons compelling slum dwellers to leave their previous location. Poor rural migrants move to the city for better life but after reaching the city, what they perceive it to be is not what they encounter hence, will continue to move within the city slums until they are capable of finding a decent place (figure 7). The funnel represents the city always welcoming new entrance.

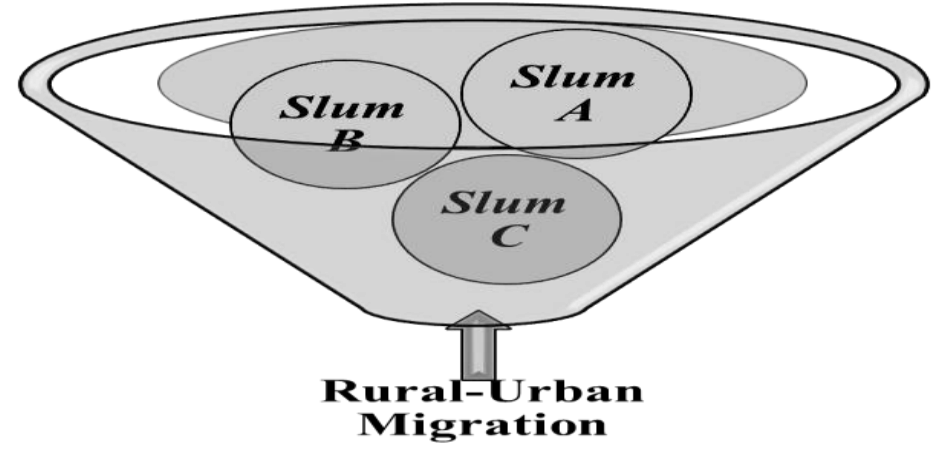

Fig. 7 The Inter-Slums Migration Funnel

The funnel represents the city (figure 7), therefore, slum dwellers will prefer to stay and move within slums until they get what they want within the city, just a few might consider the option of returning to their places of origin. For instance, from the findings of the study, $10 \%$ of respondents in Nima mentioned that they left the previous location due to the cost of rent. This means that their first point of call was not directly settling in the slums but due to the high cost of rent they relocated into the slum of Nima. Also, $5 \%$ of respondents in Nima mentioned that they had free accommodation, whilst $37 \%$ of respondent stated that they preferred this location because of low cost of rent One percent of respondents in Nima also left their previous location due to divorce and eviction respectively. This class of people needed an immediate shelter hence found solace in the slum. Evictions and demolition are mechanisms to eliminate slums in cities but they end up causing more slums, which even grow rather more rapidly since new entrance may take advantage of the condition, leading to urban population growth. The findings of the study in Old Fadama show that $5 \%$ of respondents left their previous settlement due to the cost of rent, whilst $1 \%$ moved after the divorce with their spouse (table 3). The social implication of this is that dwellers will cease any opportunity that come their way provided they will achieve the reason for which they are in the city and when they achieveit, it may serve as an incentive for new city entrance. 
Table 3 Reasons for Respondents Leaving Previous Settlement

\begin{tabular}{|c|c|c|}
\hline & PERCE & \\
\hline $\begin{array}{l}\text { Reason for Leaving Previous } \\
\text { Location }\end{array}$ & Nima & Old Fadama \\
\hline Cost of Rent & 10 & 5 \\
\hline Divorce & 1 & 1 \\
\hline Evicted & 1 & 1 \\
\hline Family Relocation & 1 & 0 \\
\hline Poor Sanitation & 1 & 1 \\
\hline Education & 7 & 7 \\
\hline Marriage & 10 & 18 \\
\hline Work & 28 & 38 \\
\hline Change of Environment & 1 & 1 \\
\hline Demolition & 22 & 2 \\
\hline Proximity to Work & 5 & 2 \\
\hline Trading & 1 & 1 \\
\hline Did Not Relocate & 11 & 20 \\
\hline Not Stated & 1 & 3 \\
\hline Total & 100 & 100 \\
\hline
\end{tabular}

Economically, job availability plays a vital role in elevating not only slum dwellers but the entire citizenry from poverty and conversely boost the economy of the country, of which Ghana is a typically example. Spatial and economic inequality has forced most citizens to move into cities where they end up settling in the slums.

Both Nima and OF have vibrant markets such as the popular Nima market, Agbogboloshie and Konkomba yam markets which often receives people from all parts of the city on daily basis. For instance, most of the young migrants who leave the northern part of Ghana and settle in OF, engage in truck pushing, kayayei (head porters) due to the proximity of the area to these markets and also, both Nima and OF have close proximity to the CBD. From the above analysis, it can vehemently be put forward that the selection of settlement by slum dwellers are based on different informed decisions and choices, some major and others minor but all constituting to the reason for settlement invariable contributing to the creation of megacities. Assumedly, the factors considered by slum dwellers for settling in a neighbourhood varies as compared to high and middle income earners, who not only consider the environment and neighbourhood but also the availability of social amenities and security. Slum formation accelerated as a result of rapid urbanization within the past 20 years particularly in the global south. 


\subsubsection{The Role of Slums in the Development of Megacities}

Slums in cities are seen as the life line of the city depending on the angle from which it is viewed. Predominantly, urban slums come about as a result of rapid urbanization and unfavourable policies. Slums have become inevitable in cities, particularly among prosperous cities of developing countries who lack the strategies of meeting the pressures of urbanization. Most slum dwellers move out of rural areas to escape from the chronic hardships and poverty of the area. Although the rural landscape may well be conducive for living, the lack of economic opportunities and spatial inequality motivates the movement of rural dwellers to cities, where they abstractly perceive or predict the type of life in the city. Sometimes from the evidence gathered by those who are returning from cities and looking "all flashy".

Slum dwellers contribute to the creation of megacities from two main perspectives as concluded by the findings of this research. First is the continuous influx of migrants into cities who find solace in slums (the place they can readily afford). They move in as a result of spatial inequality and lack of jobs. For example, in Old Fadama, more girls avail themselves in the markets as head porters (Kayayei), which needs no degree, certificate or training. The second perspective is the length of state of some migrants (lifetime migrants). They stay in the slums and start their families, who also start their own families (figure 8). Figure 8 assumes each new entrance starting a family and producing about three children, then they eventually become grandparents, creating a slum generational. Adding the new generation to the already existing population coupled with new entrance, will definitely transform the city into a mega city

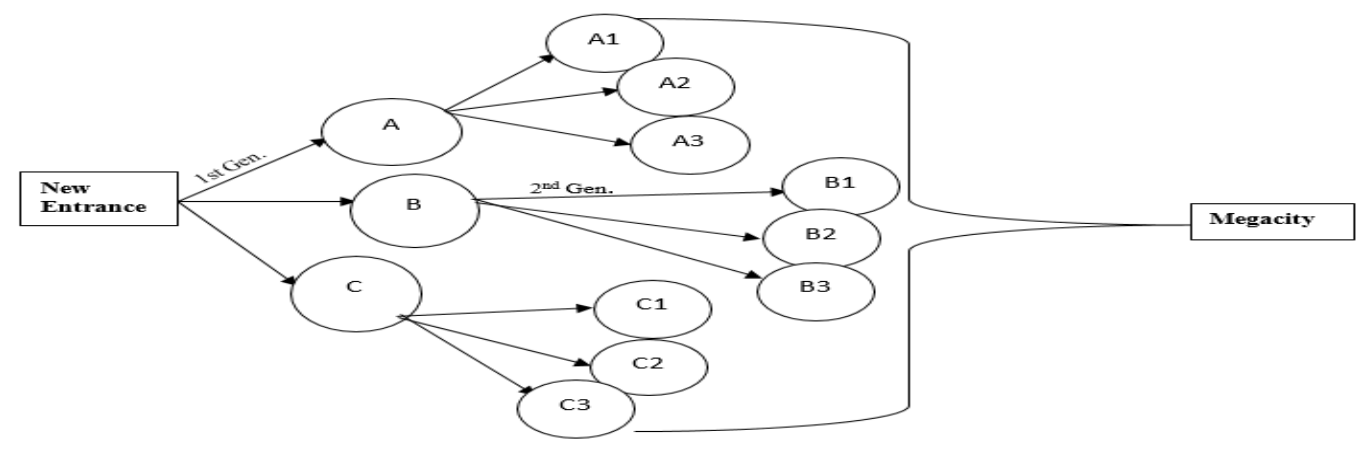

Fig. 8 A model of Generational Increase in Sums

From the statistics, the population of GAR increased from 491,1817, 851,614, 1,431,099, 2,905,726 from 1960, 1970, 1984, and 2000 respectively, to 4,010,054 in 2010(Bentsi-Enchill et al., 2013), with $40 \%$ migrating from other regions in the country. No matter how hash and hard the conditions are in the city, slum dwellers still prefer living in the city than to return to the rural area. From the study, both Nima and Old Fadama are migrant communities, therefore any action that will deny them of their source of livelihood will face strong resistance.

Megacities do not just form overnight but have been attributed to numerous factors such as the neglect of infant squatter settlements in cities amongst others as concluded in this study. For instance, slums such as Dharavi (Mumbai, India), Rocinha (Brazil), Lagos (Nigeria) are mega slums in mega cities but did not just form overnight. This means that the existence of slums contributes significantly into the rapid growth of cities (figure 9). 


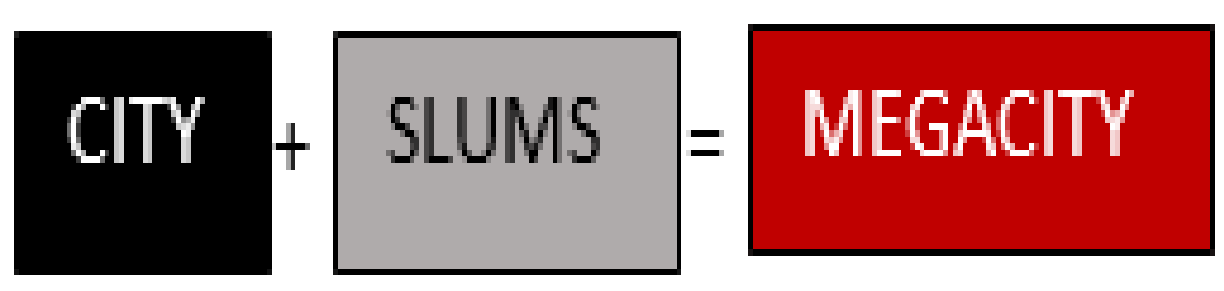

Fig. 9 Basic Urban Mathematical Equation for the growth of Megacities

As presented by some scholars, urbanisation is the increase in the proportion of the national population living in towns and results from a mixture of in-migration from rural areas and natural increase of the urban population. They stated that, the classification of a locality as urban or rural is based on population size in Ghana, that is, localities with five thousand or more people are regarded as urban(Bentsi-Enchill et al., 2013). The proportion of urban population in Greater Accra was 90.5 percent in 2010. Comparatively, GAR has the highest proportion of the population living in urban areas than other regions(Bentsi-Enchill et al., 2013). Also, the population dynamics of the cities in Ghana based on the census data from 1970-2010 show that, the country may possibly create a bipolar urban society, based on lack of proper planning and investment(Owusu and Oteng-Ababio, 2015).

Slums will continue to exist in cities unless the right strategies are put in place. Rural migrants drift into cities for greener pastures and other opportunities in the city. Mega-cities are conceptually different from world cities or global cities because they are defined by population size rather than global functions(Yeung, 2009). Megacities as already defined earlier refers to cities over 10 million. Rural to urban migrants have an enormous number moving to megacities and settling in slums(Crank and Jacoby, 2015). A megacity is a prime example of such a critical stage of development and this is principally true where growth is too rapid(Munich, 2005). Large cities always pull people to it particularly people who are captivated by densely populated areas(Munich, 2005). Urbanization attributed to rural urban migration results in the rise in numbers of poor people living in hazardous conditions(Bolay et al., 2016). 


\subsubsection{Recommendations}

Most cities of the world particularly in developing countries are rapidly urbanizing and morphing into megacities. The euphoria of rural to urban transformation amongst people is considered the global trend. However, uncontrolled movement of people coupled with natural increase is putting pressure on some cities than others. For instance, in Ghana, much pressure is centred on Accra as a result of the heavy concentration of industries, government departments and offices, and the availability of basic services. Basically, a strong political will in addressing the challenges of slums in cities, is pivotal in the planning and implementation of strategies. Granting that, the political will to deal with existing slums through adaptive measures is weak, then the political will to prepare for the future urban expansion through proactive measures will even be weaker(Mehta and Dastur, 2008). It is realistic and prudent for government, policy makers and practitioners from all angles and at all level sought out for affordable and implementable approaches and strategies in resolving challenges of global mega cities and slums. In recent years, urbanization is a global process that makes up the fast development of majority of developing countries therefore also needing prompt attention and important spatial, social and economic sustainable changes.

A comprehensive and integrated planning is clearly needed in Ghana to minimize spatial inequality. Rural areas should not only be seen as agrarian landscape, but areas needing utilities and services. Also, the one size fits all strategy must be eliminated from government policies. The development of respective regions and areas can be made peculiar with the challenges that they are facing. As the law states already, a place with 5000 or people is termed urban in Ghana hence a place ceiling maybe introduced in Ghana controlling the number of people that are permitted to live a particular urban area. Urbanization is inevitable particular within developing countries, therefore strategies for healthy urbanization is prudent especially in cities such as Accra, Kumasi, Tamale and so on.

The quest for education pushed some of the respondents to Accra, therefore, it is imperative for governments and city officials including urban planners to include the construction of schools in rural and deprived areas of the country. Slums are not a novel problem and their challenges have become a global concern, resulting in constant debates both locally and at the international level. Urban planners should provide feasible plans for government to balance efficiency and civil rights. As a matter of civil rights, citizens are to enjoy as their rights basic amenities including proper housing and water. Therefore, a gradual approach in the provision of such amenities can be rolled out. As far as the social needs and poor economic conditions of slum dwellers are not tackled, slums will continue to exist. Therefore, full consideration of civil rights in the entire country is vital. Also, Government should empower youth in the rural areas by building their capacities through skills development and livelihood support such as creating micro-credit avenues. Slum dwellers can also be empowered and sensitized on the need to return to the rural area. This can be possible through a bottom up approach such as community mobilization and sensitization.

A hybrid intervention method is needed particularly in cities to control rural-urban migration, strategies which will not end up creating more challenges in cities such as slum formations. Urban lands, both precarious and habitable lands must be guarded or utilized to prevent encroaching by particular poor rural migrants. Policy regulating rural-urban migration is paramount in reducing and avoiding the growth of megacities. Prioritizing spatial equality as the number one focus of any development agenda is eminent.

Furthermore, the study recommends healthy urban planning, that is, planning for people and putting the needs of people and communities at the heart of the urban planning 
process. Finally, the best solution to remedy slums and to prevent the growth of megacities is to prevent them.

\subsubsection{Conclusion}

Slums are often perceived as a means to an end particularly when a country is urbanizing. However, the influx of rural migrants adds to the already existing high populations of urban areas, who often reside in slums after encountering the hardships of cities and their inability to matchup with the complex conditions of the city. Therefore, this study concludes that provided the systems give room to welcome new entrance into the city, then cities will continue to grow despite the lack of infrastructure and other urban services.

Megacities are mostly categorized by extreme concentrations of people and infrastructure, however, megacities are heterogeneous and complex, just like slums. Seven of the ten most populous cities are located in developing countries(Ali and Sulaiman, 2006). Therefore, in order not to be confronted by the problems of existing in megacities, cities in developing countries must find adaptive and sustainable strategies to prevent the continuous influx of rural migrants. We conclude that, government must recognize that rapid urbanization will continue to hit developing economies and that the impact of Climate change, natural disasters, conflicts and so on, may move people from agrarian into industrialized areas, hence cities must be prepared and work towards it evolution.

\section{References}

ALI, M. H. \& SULAIMAN, M. S. The causes and consequences of the informal settlements in Zanzibar. XXIII Congress of the International Federation of Surveyors, Munich, Germany, Retrieved from https://www. fig. net/resources/proceedings/fig_proceedings/fig2006/papers/ts35/ts35_01_ali_sulaiman _0320. pdf, 2006.

AWUMBILA, M., OWUSU, G. \& TEYE, J. K. (2014), Can rural-urban migration into slums reduce poverty? Evidence from Ghana, Migrating Out of Poverty Working Paper, 13, 1-41.

BAFFOE, G. \& MATSUDA, H. (2017), "Why do rural communities do what they do in the context of livelihood activities? Exploring the livelihood priority and viability nexus", Community Development, 48, 715-734.

BENTSI-ENCHILL, N., CUDJOE, S., SEPAH, E., ANARFI, J. \& GAISIE, S. (2013), Population \& Housing Census: Regional Analytical Report Greater Accra Region, Population and Housing Census: Accra, Ghana.

BOLAY, J.-C., CHENAL, J. \& PEDRAZZINI, Y. (2016), "Slums and Precarity in Developing Countries. Learning from the Slums for the Development of Emerging Cities", Springer.

COHEN, B. (2006), "Urbanization in developing countries: Current trends, future projections, and key challenges for sustainability", Technology in society, 28, 63-80.

CRANK, J. P. \& JACOBY, L. S. (2015), "Crime, violence, and gl obal warming", Routledge.

DESA, U. (2018), Revision of world urbanizati on prospects, UN Department of Economic and Social Affairs.

GSS (2012), 2010 population and housing census: summary report of final results, Ghana Statistical Service Accra.

HABITAT, U. (2006), The state of the world's cities report 2006/2007, The millenium development goals and urban sustainability, 30 .

HABITAT, U. (2014), The state of African cities 2010, Governance, Inequalities and Urban Land Markets.,(UNEP, Nairobi, 2010).

HABITAT, U. (2016), Urbanization and development: emerging futures, World cities report, 3, 451. 
INSTITUTE, W. (2013), State of the World 2007: Our urban future, Routl edge.

KANG, S., PESCINA, J. U. C., QUASHIGAH, P. J. \& KUMASHIE, I. (2010), Nima Land Use Mapping Project, Report and Map set, Millennium Cities Initiative.

KOTHARI, C. R. (2004), Research methodology: Methods and techniques, New Age International.

LEARNER, A. (2017), The habitable planet: A systems approach to environmental science.

LUCCI, P., BHATKAL, T., KHAN, A. \& BERLINER, T. (2015), What works in improving the living conditions of slum dwellers, ODI Dimenstion Paper, 4.

MEHTA, B. E. \& DASTUR, A. (2008), Approaches to urban slums: a multimedia sourcebook on adaptive and proactive strategies, The World Bank.

MUNICH, R. (2005), Megacities-Megarisks: Trends and challenges for insurance and risk management, Munich Re.

NATIONS, U. (2002), World Urbanization Prospects, The 2001 Revision: Data Tables and Highlights, World Urban Prospect 2003 Revis, 1-195.

OBENG-ODOOM, F. (2010), "An urban twist to politics in Ghana", Habitat International, 34, 392399.

OWUSU, G., AGYEI-MENSAH, S. \& LUND, R. (2008), "Slums of hope and slums of despair: Mobility and livelihoods in Nima, Accra", Norsk Geografisk Tidsskrift-Norwegian Journal of Geography, 62, 180-190.

OWUSU, G. \& OTENG-ABABIO, M. (2015), "Moving unruly contemporary urbanism toward sustainable urban development in Ghana by 2030", American Behavioral Scientist, 59, 311-327.

SETTLEMENTS, P. S. D. O. H. (2010), Final draft report on community-led enumeration of Old Fadama community, Accra-Ghana, Author Accra.

SRINIVAS, H. (2005), Defining squatter settlements. Global Development Research Center Web site, www. gdrc. org/uem/define-squatter. html, viewed, 9.

TACOLI, C., MCGRANAHAN, G. \& SATTERTHWAITE, D. (2015), Urbanisation, rural-urban migration and urban poverty, Human Settlements Group, International Institute for Environment and Development.

TAUBENBÖCK, H., ESCH, T., FELBIER, A., WIESNER, M., ROTH, A. \& DECH, S. (2012), "Monitoring urbanization in mega cities from space", Remote sensing of Environment, 117, 162-176.

UN-HABITAT (2011), Ghana housing profile, Author Nairobi.

UN-HABITAT (2015), Slum almanac 2015-2016: Tracking improvement in the lives of slum dwellers, United Nations Human Settlements Programme (UN-Habitat) Nairobi, Kenya.

YEUNG, Y.-M. (2009), Mega-cities. 